高知県浦ノ内湾におけるミドリイガイの生息場所利用と水平分布

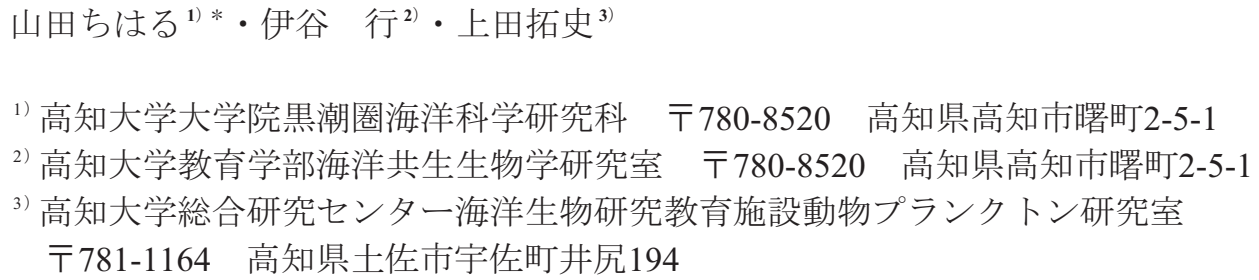

\title{
Habitat use and horizontal distribution of the green mussel, Perna viridis, in Uranouchi Inlet, Kochi Prefecture
}

\author{
Chiharu Yamada, ${ }^{1}{ }^{*}$ Gyo Itani, ${ }^{2)}$ Hiroshi Ueda ${ }^{3)}$ \\ 1) Graduate School of Kuroshio Science, Kochi University, 2-5-1 Akebono, Kochi 780-8520, Japan \\ 2) Laboratory of Marine Symbiotic Biology, Faculty of Education, Kochi University, 2-5-1 Akebono, Kochi 780- \\ 8520, Japan \\ 3) Laboratory of Zooplankton Ecology and Taxonomy, Usa Marine Biological Institute, Kochi University, Inoshiri \\ 194, Usa, Tosa, Kochi 781-1164, Japan \\ * Corresponding Author: C. Y. e-mail: urahic566@hotmail.com
}

(Received April 4, 2009; Accepted September 28, 2009)

\begin{abstract}
The green mussel, Perna viridis, is an invasive species, that has been expanding its geographic range in warmer Japanese waters recently. To elucidate its habitat use pattern, its distribution was investigated in Uranouchi Inlet, Kochi Prefecture, Japan ( $33^{\circ} 26^{\prime} \mathrm{N}, 133^{\circ} 25^{\prime} \mathrm{E}$ ), from March to May, 2008. Intertidal surveys revealed that $P$. viridis uses natural rocky shores and cobble shores as well as artificial vertical seawalls and block seawalls. No difference in its abundance was detected among the four habitat types. Green mussels were more abundant in the inner bay and middle bay than in the outer bay. They were also found on floats of fish-farming rafts. The total abundance of $P$. viridis in Uranouchi Inlet was estimated 240,000 individuals on floats and 50,000 on intertidal shores. The distribution of another invasive mussel, Xenostrobus securis, was also surveyed in Uranouchi Inlet, along with the Japanese native mussels $X$. atratus, Hormomya mutabilis, Septifer bilocularis, and S. virgatus. Perna viridis overlapped with $H$. mutabilis and $S$. bilocularis. The high abundance of $P$. viridis and its invasion of natural shores possibly represents a threat to the indigenous mussel species community, but further ecological research is needed to evaluate the scale of this threat.
\end{abstract}

Key words: fouling organisms, green mussel, Perna viridis, invasive species, habitat use 


\section{緒 言}

ミドリイガイPerna viridisはインド〜西太平洋の熱 帯域を原産とするイガイ科の二枚貝類で、中国や日本沿 岸、さらに米国南東部やカリブ海などに移入して広大な 分布域を有する (Sidda11，1980; Baker et al., 2007)。 本種の日本への移入は1967年が初記録であるが1970年代 には記録が途絶え、1980年代の再発見以後、特に1990年 以降に太平洋沿岸と瀬戸内海で急速に分布が拡大してい る（植田、2001; 劉・渡辺、2002; 岩崎ほか、2004）。 移入に至った経路や方法の特定は難しいが、船体への付 着やバラスト水などが疑われている（岩崎ほか、2004）。 また、本種は長い浮遊幼生期をもつことから、東南アジ アから幼生が黒潮に流されて自然分散した個体もしくは 個体群がある可能性も否定出来ない（横川・鍋島、1998; 大垣、2007)。日本における本種の生息限界水温は $10^{\circ} \mathrm{C}$ 前後である可能性が示され、冬期に死亡する個体が多い が、内湾域の発電所等の温排水放水口付近に加え、相模 湾や紀伊水道など温暖域各地で越冬個体が認められてい る（梅森・堀越、1991; 羽生・関口、2000; 植田、2001; 岩崎ほか、2004）。さらに生殖腺の周年観察から、日本 で本種の再生産が行われていることが確認されている （吉安ほか、2004）。

日本において、ミドリイガイは発電所や工場の冷却水 取水・排水口、防波堤、消波ブロック、養殖いけす、係 留ロープ、およびブイなどの人工基盤をハビタットとし て利用することが多いが、自然岩礁に付着することもあ る（植田、2000；2001）。移入種であるミドリイガイが 自然海岸に生息域を広げているとすると、在来の付着生 物との競合が懸念されるが、付着基質に着目した本種の 分布状況の記述は不足している。そこで本研究では、高 知県浦ノ内湾の潮間帯にて、本種と他のイガイ類の水平 分布および付着基質による分布に焦点を当てて調査を行っ た。浦ノ内湾では、ミドリイガイは 2000 年頃から生息が 認められるようになり、現在では $1-2$ 月の低水温期を 経た春先にも殼長 $70 \mathrm{~mm}$ を超えるような大型個体を含む個 体群が確認されている (山田、未発表)。低水温期直後 に本種の幼生が着底したと仮定して、その $1 、 2$ 力月後 の春までに款長 $70 \mathrm{~mm}$ ま゙成長するとは考えにくいことか ら、浦ノ内湾においてミドリイガイの越冬は可能である と考えられる。当湾のように発電所や工場の温排水が流 入しない越冬可能な地域におけるミドリイガイの生息場 所利用を記述することは、今後、本種の日本における分 布拡大に際して、重要な知見となると考えられる。また、 浮体構造物は人工基盤として特徵的な生物群集が形成さ れ (Holloway and Connel1, 2002)、ミドリイガイの付 着基盤として海岸とともに一般的である（植田、 2001)。当湾に設置されている浮体構造物として、筏の フロート下面をハビタットとして利用している、潮下帯 のミドリイガイの水平分布調査も行った。また、それぞ れのハビタットにおける殼長組成から、ミドリイガイの 個体群特性についても記述した。

\section{材料および方法}

\section{1. 調査地}

浦ノ内湾は土佐湾のほぼ中央部に位置する入江である (Fig. 1)。湾が東西に細長く伸びて水の交換が悪いため 内湾性が強く、湾口から湾奥にかけて環境が変化する (八塚・今村、1965)。

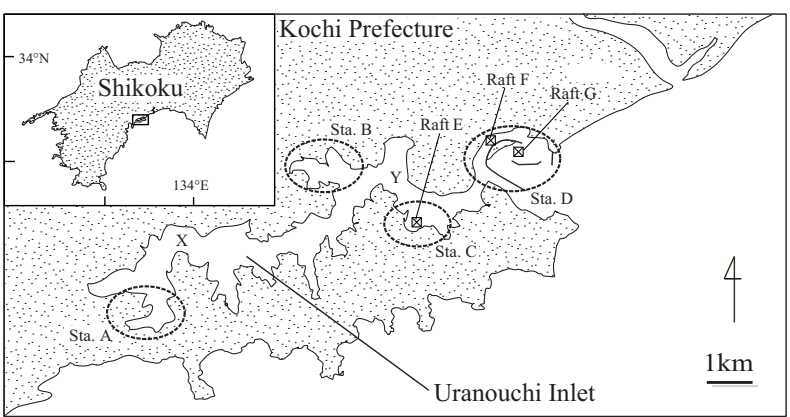

Fig. 1 Locations of the study sites. Stations A, B, C, and D are the sampling areas for intertidal surveys, including 12 sites altogether on rocky shores, cobble shores, vertical seawalls, and block seawalls. Rafts E, F, and G were the sites of subtidal surveys. $\mathrm{X}$ and $\mathrm{Y}$ are the observation sites of the Kochi Prefectural Fisheries Experimental Station for monthly water temperature and salinity records.

2006年 6 月から 2008年 5 月までの高知県水産試験場の 資料（林、2008; 高知県水産試験場、未発表）によれば、 湾内の表層海水の温度は湾奥の定点X（Fig. 1）で平均 水温が $20.9^{\circ} \mathrm{C}$ (最高 $31.0^{\circ} \mathrm{C}$ 、最低 $9.7^{\circ} \mathrm{C}$ )、湾口側の定点 Yでは、平均水温が $21.8^{\circ} \mathrm{C}$ (最高 $30.3^{\circ} \mathrm{C}$ 、最低 $13.8^{\circ} \mathrm{C}$ ) であった（Fig. 2a）。湾奥では、外洋水の影響が弱いた め、冬期には湾口側より低温となる。また、同じ資料に よると、塩分は定点Xでは平均 28.7 (最高33.1、最低 16.7）、定点Yでは平均30.6（最高33.9、最低21.4）であ り、降雨による塩分の低下が春から夏に見られる（Fig. 2b)。

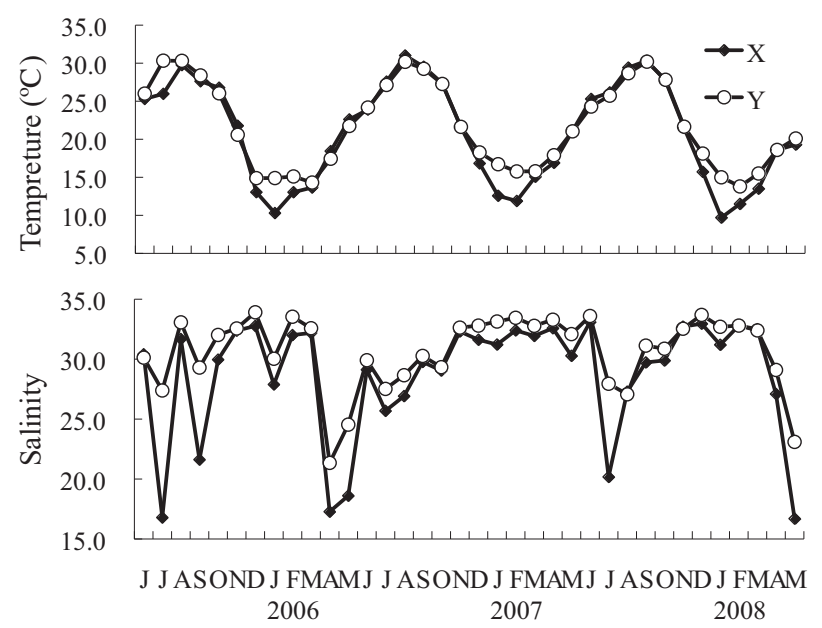

Fig. 2 Seasonal changes of a) surface water temperature and b) salinity in Uranouchi Inlet from June, 2005, to May, 2008 (data provided by Kochi Prefectural Fisheries Experimental Station). 


\section{2. 潮間帯における分布調査}

浦ノ内湾の湾奥、湾央、湾口、および湾外にそれぞれ 調查区A、B、C、およびDを設けた（Fig. 1)。各調査区 内に自然海岸として岩礁海岸（RS：rocky shore）と転 石海岸 (CS： cobble shore)、人工海岸として垂直護岸 (VS： vertical seawall) と石組み護岸 (BS： block seawa11）の 4 種類の海岸タイプをそれぞれ 3 地点ずつ、 つまり各調査区内に計12地点のハビタットを調査地点と して設定した。岩礁海岸と転石海岸はなだらかな傾斜を 持つ天然基質であり、垂直護岸はほぼ垂直なコンクリー トで、石組み護岸はコンクリートまたは天然石がなだら かな傾斜となるよう配置されている（Fig. 3)。各調查 地点では、2008年 5 月 5 日から 9 日、および23日の大潮 干潮時に 2 名の調査者が10分間、海岸線に沿ってイガイ 科二枚貝類を探索し、出現種を記録した。探索範囲は潮 上帯から水深 $30 \mathrm{~cm}$ 程度の潮下帯までとした。移入種であ るミドリイガイとコウロエンカワヒバリガイ Xenostrobus securisについては個体数も記録し、発見 出来た全ての個体を調査時間中に採集した。ただし、積 み重なった石組みの間隙に付着している個体など迅速な 採集が困難な場合は、例外的に調査時間外に採集を行っ た。採集標本は実験室にて殼長を測定した。潮間帯にお ける調査範囲は、汀線に水平な距離として記述すると、 岩礁海岸で平均 $10 \mathrm{~m}$ (標準偏差 $2 \mathrm{~m}$ )、転石海岸で平均 $20 \mathrm{~m}$ (同 $7 \mathrm{~m}$ )、垂直護岸で平均 $11 \mathrm{~m}$ (同 $6 \mathrm{~m}$ )、石組み 護岸で平均 $12 \mathrm{~m}$ （同 $5 \mathrm{~m}$ ）であった。

出現が認められたイガイ類は、調査区およびハビタッ
トについて、種ごとにそれぞれの出現率（12調査地点の うちの出現地点数の割合）を算出した。調查区Bおよび 調査区Cにおける転石海岸と石組み護岸では、潮間帯中 部から上部に垂直護岸が設置されている地点が存在し、 調査区Bでは転石海岸の 1 地点と石組み護岸の 2 地点、 調査区Cではそれぞれ 2 地点と 1 地点が該当した。よっ て、このような地点では、潮間帯中部から上部に生息す るコウロエンカワヒバリガイおよびクログチX. atratus の出現をカウントせず、これらの出現率はその他の 9 地 点中の割合で示した。ミドリイガイについては、調査区 およびハビタットについてそれぞれの平均採集個体数と 標準偏差を求めた。また、 $\log$ （個体数+0.5）に変換後 (Yamamura，1999)、2 元配置分散分析と、Tukey-Kramer のHSD検定を行なった。

各ハビタットから比較的多数のミドリイガイが採集さ れた調查区Bについては、Mann-WhitneyのU検定を用いて 自然海岸の岩礁海岸と転石海岸、人工海岸の垂直護岸と 石組み護岸の間で殼長組成の相違の有無を検討した。調 査区Aでは岩礁海岸と垂直護岸から多数のミドリイガイ が採集されたので、岩礁海岸と垂直護岸について調査区 $\mathrm{A}$ と調査区Bの間で殸長組成の相違の有無の検討を行なっ た。これらの殼長組成については、Hasselblad（1966） に従い、殼長組成が複数の正規分布に分離出来るか否か を検討した。プログラムはFiSAT II（ver. 1.2.2，FA0， Rome, Italy) に組み込まれているNORMSEPを用いた (Gayanilo et al., 2005)。 a)

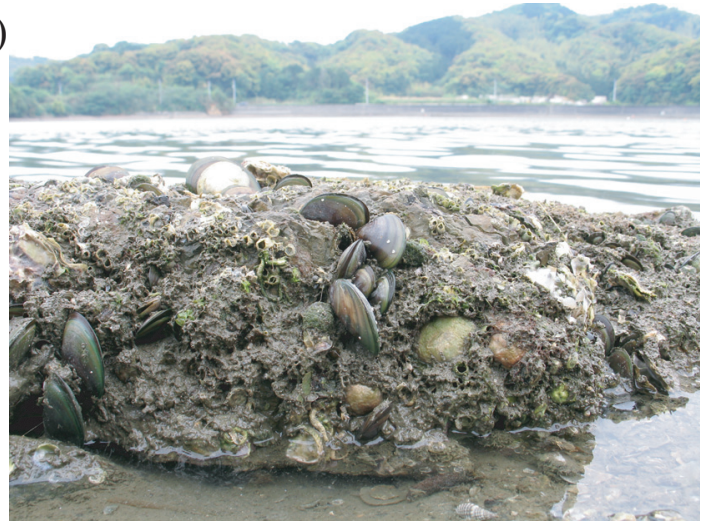

c)

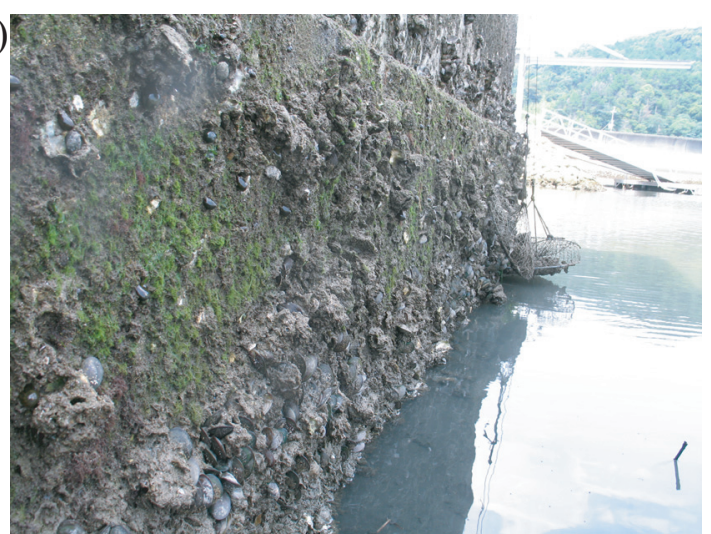

b)

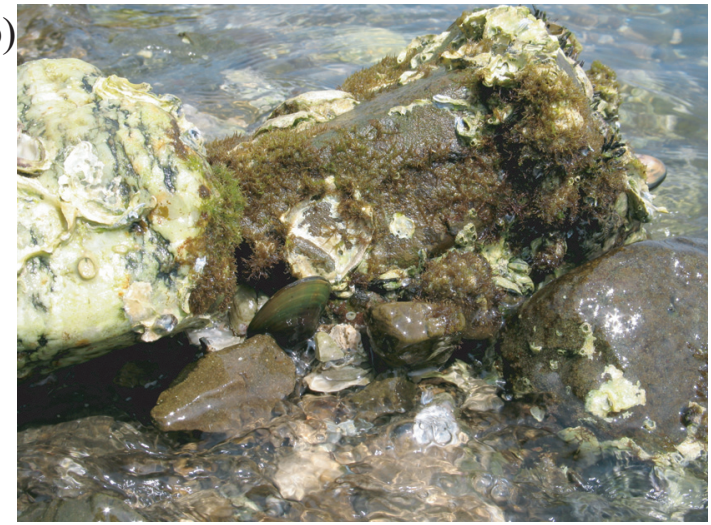

d)

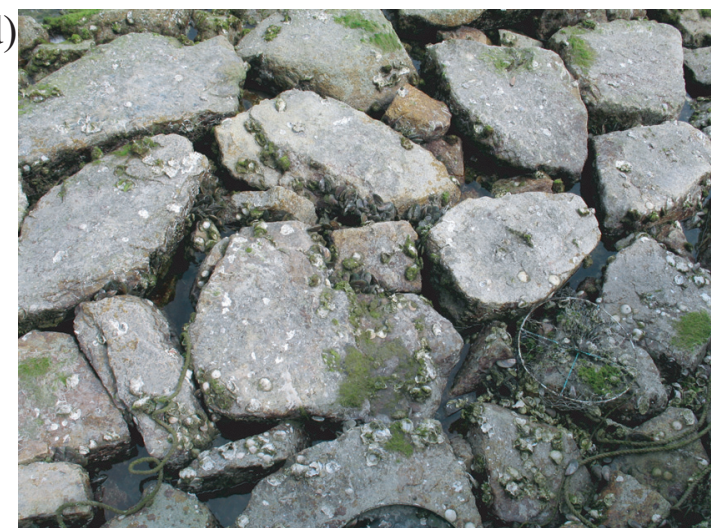

Fig. 3 Representative habitat types for intertidal surveys in Uranouchi Inlet. a) rocky shore, b) cobble shore, c) vertical seawall, and d) block seawall. 


\section{3. 浮体構造物（筏のフロート下面）における分布調査}

浦ノ内湾では、湾口から湾央にかけて高密度に養殖筏 が設置されており、ハマチやマダイの養殖が盛んである が、必ずしも養殖対象物や利用時期が一様ではない。ま た、アコヤガイ、ヒオウギ、およびマガキの養殖はほと んど行われていない。本研究では、現在養殖に利用され ておらず、少なくとも設置後 3 年が経過している筏とし て、浦ノ内湾の湾口に設置された筏E、湾外で防波堤に より波当たりの緩やかな区域に設置された筏Fおよび湾 外のやや波当たりの強い区域に設置された筏Gを調查対 象とした。

筏Eでは2008年 3 月 12 日に改修のため陸揚げされた際 に、笺Fおよび筏Gについては2008年 4 月 17 日に潜水して 調査を行った。筏の底面には、黒色のビニールシートを 巻き付けられた円柱形のフロート（発泡スチロール製、 直径 $60 \mathrm{~cm}$ 、長さ $90 \mathrm{~cm}$ ) が複数固定されている。それぞれ の筏からフロートを無作為に 7 つ選び、フロート下面に $33 \times 33 \mathrm{~cm}$ のコドラートを設定し、コドラート内の付着物 を全て採集し実験室に持ち帰った。実験室ではイガイ類 の有無と種名を記述した。ミドリイガイについては個体 数と殼長を測定し、平均採集個体数と標準偏差を算出し た。また、 $\log$ （個体数＋0.5）に変換後（Yamamura, 1999）、1 元配置分散分析と、Tukey-KramerのHSD検定を 行った。さらに、比較的多数のミドリイガイが採集され た筏Fについては、FiSAT II (ver. 1.2.2, FA0, Rome, Italy）のNORMSEPを用いて殼長のピークの記述を行なっ た (Gayanilo et al., 2005)。

\section{4. 浦ノ内湾内におけるミドリイガイ生息数の推定}

浦ノ内湾内におけるミドリイガイの生息数を、潮間帯 （調查区A、B、C）および浮体構造物（筏E）の調査結果 より算出した。Google Earth ${ }^{\mathrm{TM}}$ の航空写真をもとに湾内 の海岸線の距離および養殖筏の総面積を計測すると、海 岸線は $56 \mathrm{~km}$ であり、湾内に設置された養殖筏の数は筏 $\mathrm{E}$ の面積に換算しておよそ900個分であった。笺Eにはフロー

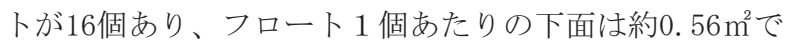
あることから、湾内のフロート下面の面積はおよそ 8, $000 \mathrm{~m}^{2}$ であると考えられた。これらのデータを用いて、 浦ノ内湾内におけるミドリイガイの生息数を推定した。

\section{結 果}

\section{1. 潮間帯における分布調査}

採集されたイガイ科二枚貝類は、ミドリイガイとコウ ロエンカワヒバリガイ、クログチ、ヒバリガイモドキ Hormomya mutabilis、クジャクガイSeptifer bilocularis、 およびムラサキインコ S. virgatusの計 6 種であった。 これら 6 種のイガイ類の出現状況をTable 1に示した。 ミドリイガイは湾内の調查区（調査区A、B、C）で出現 率が高く、湾外（調査区D）では低かった。一方、異な るハビタット間、つまり、自然海岸である岩礁海岸と転 石海岸および人工海岸である垂直護岸と石組夕護岸にお ける出現率は同程度であった。コウロエンカワヒバリガ イは湾奥の調査区Aから湾央の調査区Bの垂直護岸および
岩礁海岸においてにのみ分布が確認された。クログチは 調査区Aから調査区Bにかけては、ほぼ全ての調査地点で 出現したが、湾口の調査区Cおよび湾外の調査区Dにおけ る出現率はやや低下した。本種は 4 種全てのハビタット で出現した。ヒバリガイモドキは全ての調査区およびハ ビタットで出現したが、湾内の出現率は低く、特に湾外 で高頻度に出現した。クジャクガイは調査区Aには出現 せず、調査区Bから調査区Dにかけて全てのハビタットで 出現した。ムラサキインコは湾内の調査区には出現せず、 調査区Dにのみ全てのハビタットで出現した。

ミドリイガイの各調査あたり（ 2 人で 10 分間）の平均 採集個体数と標準偏差を、調査区についてはFig.4aに、 ハビタットについてはFig. 4bに示した。2 元配置分散 分析を行なった結果、調査区間で有意な差があるが $\left(F_{(3,32)}=6.981, P=0.001\right) 、$ 八ビタット間では有意 な差がなく $\left(F_{(3,32)}=0.516, \quad P=0.678\right)$ 、調查区と八 ビタットの交互作用は有意ではなかった $\left(F_{(9,32)}=\right.$ 1. 873, $P=0.093) 。 T u k e y-K r a m e r の H S D$ 検定の結果、調

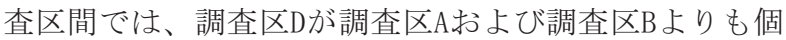
体数が少なかったが、湾内の 3 つ調査区で有意差は検 出されなかった。
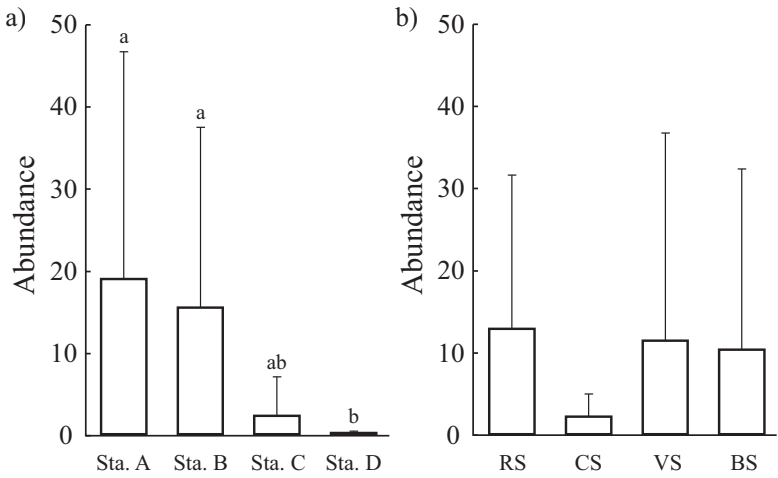

Fig. 4 Individual number (mean $\pm \mathrm{SD}$ ) of Perna viridis collected by two persons for ten minutes in the intertidal zone $(\mathrm{n}=12)$. a) Spatial distribution. b) Habitat utilization. Different letters above the SD bars indicate statistically significant differences among stations using log (x +0.5 )-transformed data (Tukey-Kramer's post-hoc test, $P<0.05)$. No significant differences were found among habitats. RS, rocky shore; CS, cobble shore; VS, vertical seawall; BS, block seawall.

\section{2. 浮体構造物（筏のフロート下面）における分布調査}

筏のフロート下面からは、ミドリイガイ、ヒバリガイ モドキ、およびタマエガイMusculus cupreusの 3 種の イガイ類が採集された。ミドリイガイについてコドラー トあたりの平均採集個体数と標準偏差をFig. 5に示した。 1 元配置分散分析を行った結果、ミドリイガイの密度は 有意に異なり $\left(F_{(2,18)}=37.159, \quad P<0.0001\right) 、$ TukeyKramerのHSD検定の結果、筏Fの密度が有意に高かった。 
Table 1. Frequency of occurrence of mytilid bivalves in different habitats in Uranouchi Inlet. The number of sampling sites in each habitat in a sampling area is three, except as indicated by asterisk(s) for Xenostrobus species. *: two sites, **: one site.

\begin{tabular}{|c|c|c|c|c|c|c|}
\hline Species & habitat type & Sta. A & Sta. B & Sta. C & Sta. D & Total (\%) \\
\hline \multirow[t]{5}{*}{ Perna viridis } & Rocky shore & 2 & 2 & 1 & 1 & 50 \\
\hline & Cobble shore & 1 & 3 & 3 & 0 & 58 \\
\hline & Vertical seawall & 2 & 2 & 1 & 0 & 42 \\
\hline & Block seawall & 2 & 3 & 1 & 0 & 50 \\
\hline & Total $(\%)$ & 58 & 83 & 50 & 8 & \\
\hline \multirow[t]{5}{*}{ Xenostrobus securis } & Rocky shore & 2 & 1 & 0 & 0 & 25 \\
\hline & Cobble shore & 0 & $0 *$ & $0 * *$ & 0 & 0 \\
\hline & Vertical seawall & 1 & 0 & 0 & 0 & 8 \\
\hline & $\underline{\text { Block seawall }}$ & 0 & $0 * *$ & $0 *$ & 0 & 0 \\
\hline & Total (\%) & 33 & 11 & 0 & 0 & \\
\hline \multirow[t]{5}{*}{ Xenostrobus atratus } & Rocky shore & 3 & 3 & 3 & 1 & 83 \\
\hline & Cobble shore & 3 & $1 *$ & $0^{* *}$ & 1 & 56 \\
\hline & Vertical seawall & 3 & 3 & 2 & 2 & 83 \\
\hline & Block seawall & 3 & $1 * *$ & $0 *$ & 2 & 67 \\
\hline & Total (\%) & 100 & 89 & 56 & 50 & \\
\hline \multirow[t]{5}{*}{ Hormomya mutabilis } & Rocky shore & 0 & 2 & 1 & 2 & 42 \\
\hline & Cobble shore & 0 & 0 & 1 & 1 & 17 \\
\hline & Vertical seawall & 1 & 0 & 0 & 2 & 25 \\
\hline & Block seawall & 0 & 0 & 0 & 2 & 17 \\
\hline & Total (\%) & 8 & 17 & 17 & 58 & \\
\hline \multirow[t]{5}{*}{ Septifer bilocularis } & Rocky shore & 0 & 0 & 3 & 3 & 50 \\
\hline & Cobble shore & 0 & 1 & 3 & 2 & 50 \\
\hline & Vertical seawall & 0 & 2 & 3 & 1 & 50 \\
\hline & $\underline{\text { Block seawall }}$ & 0 & 1 & 3 & 2 & 50 \\
\hline & Total $(\%)$ & 0 & 33 & 100 & 67 & \\
\hline \multirow[t]{5}{*}{ Septifer virgatus } & Rocky shore & 0 & 0 & 0 & 1 & 8 \\
\hline & Cobble shore & 0 & 0 & 0 & 1 & 8 \\
\hline & Vertical seawall & 0 & 0 & 0 & 2 & 17 \\
\hline & Block seawall & 0 & 0 & 0 & 1 & 8 \\
\hline & Total (\%) & 0 & 0 & 0 & 42 & \\
\hline
\end{tabular}

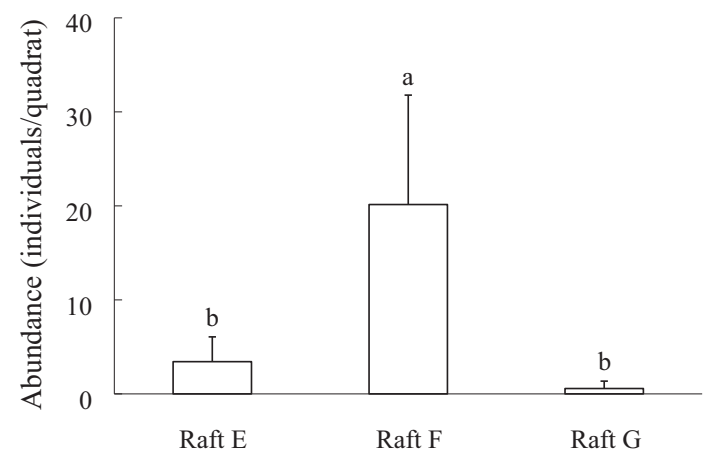

Fig. 5 Individual number (mean $\pm \mathrm{SD}$ ) of Perna viridis on undersurfaces of floats $(n=7)$. Different letters above the SD bars indicate statistically significant differences among rafts using $\log (\mathrm{x}+0.5)$-transformed data (TukeyKramer's post-hoc test, $P<0.05)$

\section{3. 浦ノ内湾内におけるミドリイガイの生息数}

分布調査の結果から、湾内におけるミドリイガイの平 均密度は、潮間帯では海岸線 $1 \mathrm{~m}$ あたり 0.9 個体、フロー
ト下面では $1 \mathrm{~m}^{2} あ た り 31$ 個体であった。Google Earth ${ }^{\mathrm{TM}}$ を用いた測定によって、湾内における海岸線は56km、フ ロート下面の面積はおよそ $8,000 \mathrm{~m}^{2}$ と算出されたことか ら、浦ノ内湾内の潮間帯にはおよそ50,000個体、養殖筏 のフロート下面にはおよそ240,000個体のミドリイガイ が生息していると推定された。

\section{4. 移入種の殼長組成}

採集されたミドリイガイの殼長組成を調查区別（Fig. 6）および筏別（Fig. 7）に示した。Mann-WhitneyのU検 定の結果、殼長は調査区Bでは、岩礁海岸よりも転石海

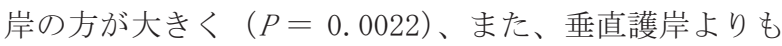
石組夕護岸の方が大きかった $(P<0.0001)$ 。岩礁海岸 で比較すると、調査区Aよりも調査区Bの方が大きく（ $P$ $=0.0115)$ 、垂直護岸では調査区 $A$ と調査区Bに有意な差 は認められなかった $(P=0.0503) 。$

殼長組成のコホート解析の結果、調査区Aでは岩礁海 岸で 1 つのピーク (殼長 $35 \mathrm{~mm}$ )、垂直護岸でも 1 つのピー ク（款長 $32 \mathrm{~mm} ）$ のみが確認された。調査区Bでは、岩礁 海岸で款長 $29 \mathrm{~mm}$ と $63 \mathrm{~mm}$ の 2 つのピークが認められたが、 

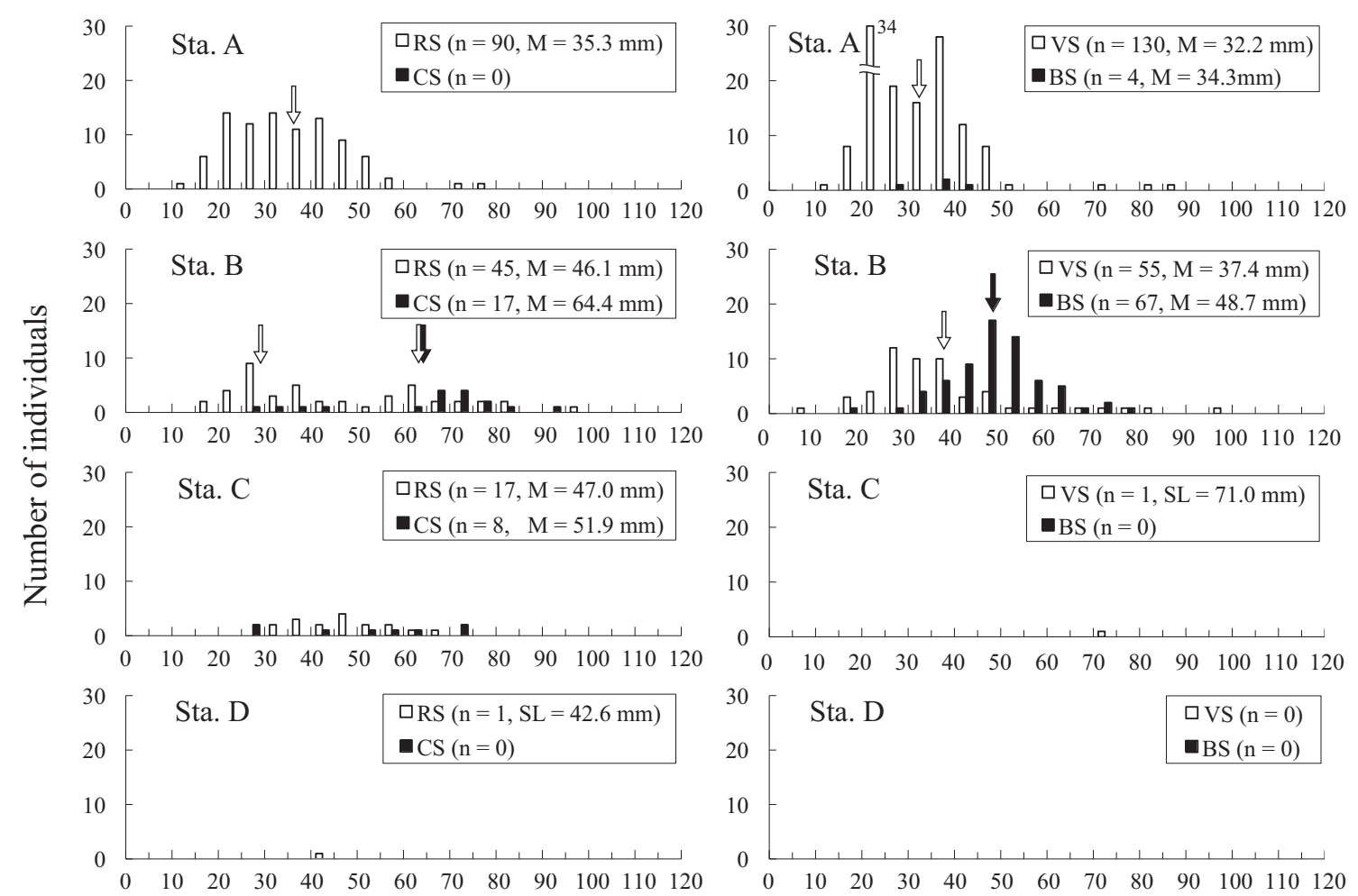

Shell length (mm)

Fig. 6 Size structure of Perna viridis collected from natural (left) and artificial (right) intertidal zone surfaces. The bars represent the number of individuals collected from each habitat. RS, rocky shore; CS, cobble shore; VS, vertical seawall; BS, block seawall; $\mathrm{n}$, number of measured individuals; M, mean shell length; SL, shell length.

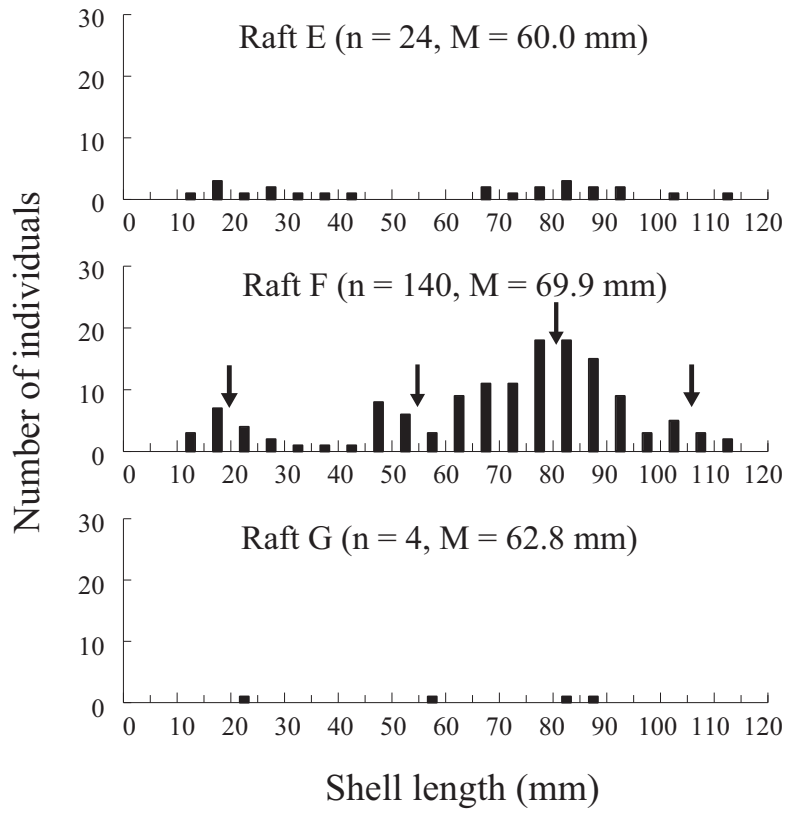

Fig. 7 Size structure of Perna viridis collected from undersurfaces of floats. Arrows indicate the mean shell length of each cohort. n, number of measured individuals; M, mean shell length.

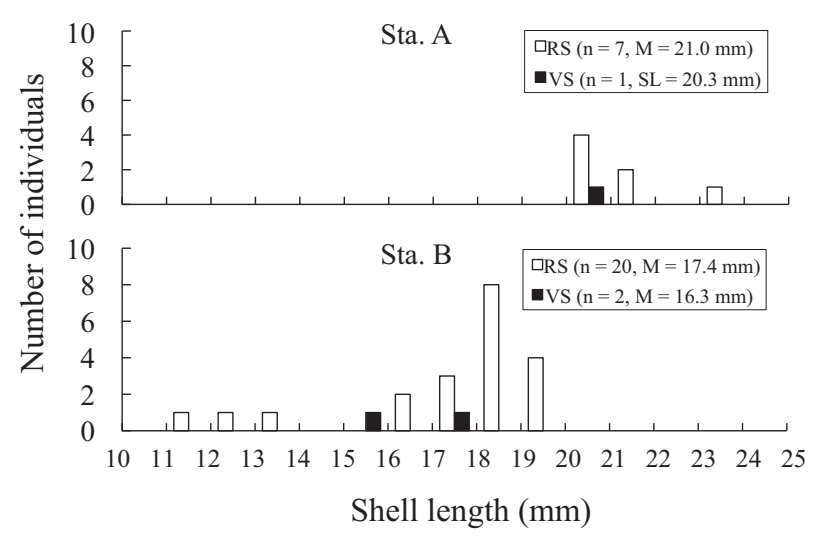

Fig. 8 Size structure of Xenostrobus securis collected from the intertidal zone. The bars represent the number of individuals collected from each habitat. RS, rocky shore; VS, vertical seawall; $n$, number of measured individuals; M, mean shell length; SL, shell length.

他のハビタットでは複数のピークは認められず、転石海 岸では64mm、垂直護岸では38mm、石組み海岸では $49 \mathrm{~mm}$ ピークとなった。一方、潮下帯の筏Fでは 4 つのピーク

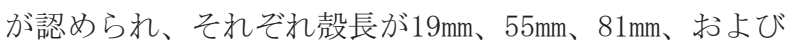
106mmであった。 
採集されたコウロエンカワヒバリガイの殼長組成を Fig. 8に示した。調査区Aの岩礁海岸における平均款長 は21. $0 \mathrm{~mm}(\mathrm{n}=7)$ 、垂直護岸より採集された唯一の個 体の殼長は20.3 mmであった。調査区Bでは、岩礁海岸で $17.42 \mathrm{~mm}(\mathrm{n}=20)$ 、垂直護岸で $16.3 \mathrm{~mm}(\mathrm{n}=2)$ であっ た。

\section{考 察}

1. 浦ノ内湾におけるミドリイガイの分布と個体群特性

本州におけるミドリイガイの生活史は明らかではない が、本種の着底が夏から秋に認められた事例が知られて おり（岡ら、1991; 羽生・関口、2000; 植田、2001）、

岡ら（1991）によると、着底後数ヶ月間の成長は、毎月 およそ $10 \mathrm{~mm}$ である例が示されている。浦ノ内湾における 本種の着底期は明らかではないが、仮に $1-2$ 月の最低 水温期間の後、3 月に本種の幼生が着底しても、4-5 月までの間に殼長 $40 \mathrm{~mm}$ でに成長するとは考えにくい。 羽生・関口（2000）も推定している通り、本研究におい ても調査期間中に採集されたミドリイガイのうち、殼長 40mmを超える個体は確実に越冬個体であると考えられる。

浦ノ内湾の湾口付近は黒潮の影響を受けた外洋水が流 入するために、冬期水温は $15^{\circ} \mathrm{C}$ 前後までしか低下しない のに対して、湾奥部では水温が $10^{\circ} \mathrm{C}$ 前後までに低下する (林、2008; 高知県水産試験場、未発表)。熱帯種である ミドリイガイの生存限界水温は $10^{\circ} \mathrm{C}$ 前後であるとされる が、本邦において水温が $10^{\circ} \mathrm{C}$ 前後に低下しても越冬の認 められる地域があり（劉・渡辺、2002）、本調査におい ても、湾奥で多数のミドリイガイが採集されている。越 冬個体が耐寒性を持つ個体であり、そのような個体が繁 殖しているとすると、今後、日本で耐寒性を持つミドリ イガイが増加し、さらに分布域が広がる可能性がある。

ミドリイガイの主な生息場所は内湾等の浅海域であり、 塩分に関しては、およそ27-35が好適であるとされてい るが、インドのベンガル湾のように塩分が5.2-39.8と幅 広い環境にも生息する例もある（劉・渡辺、2002）。浦 ノ内湾では、湾奥と湾口では水温の他に塩分環境も異な り、湾奥では季節的に 17 前後の低塩分となるが、湾内に おける潮間帯の 3 つの調査区については、ミドリイガイ の採集個体数に有意差は認められなかった。一方、湾外 では湾奥および湾央部に比べ、ミドリイガイの採集密度 は有意に低い。湾外における環境要因のデータは示して いないが、水温および塩分については湾口よりやや高い と推測され、これらがミドリイガイの低密度の要因であ るとは考えにくい。すなわち、水温および塩分は、当湾 における潮間帯のミドリイガイの水平分布を説明する要 因とはならず、餌となるプランクトン量や波浪条件等、 他の要因によって影響を受けることが予想される。また、 潮間帯の異なる八ビタット間において採集密度の有意差 が認められなかったことから、付着基盤もミドリイガイ の分布の制限要因とはならない可能性が示唆された。一 方、干出の影響を受けないフロート下面においては、湾 外の筏Fで有意に高密度となり、潮閒帯における水平分
布とは一致しない。これは、筏Fが防波堤と岸壁の間に 設置されているため、䇝EおよびGと比べて波浪の影響を 受けにくいことが要因として考えられるが、本研究の調 查結果からは明らかにすることは出来なかった。 Rajagopal et al. (1998) は、流れが速い場所ではミド リイガイ幼生の着底の機会が高まる可能性を示唆してい るが、笺Fは湾口寄りに位置するため、潮流の影響をよ り受けやすい。宮脇・関口（2000）によると、ベントス の分布は成体が受ける要因だけではなく、浮遊幼生の分 布や着底・加入過程にも起因するとされている。今後は、 これらを考慮したさらなる調査研究が必要であると考え られる。

ミドリイガイの個体群動態については海外で多くの研 究がある(劉・渡辺、2002 ; Rajagopal et al., 2006) が、日本での研究例はほとんどない。本調査において、 ミドリイガイの殼長組成は、湾奥部では岩礁海岸、垂直 護岸とも殼長32-35mmを中とした一山型であるのに対 し、湾央部では岩礁海岸で殼長 $29 \mathrm{~mm}$ と $63 \mathrm{~mm}$ をピークとす る双峰型となった。湾央部では他のハビタットでも、殼 長60-80mmの個体が比較的多数採集されている。このよ うに款長組成が異なる理由として、浦ノ内湾では湾央か ら湾奥部の海底が夏期に貧酸素となる（玉井・森本、 1990 ；伊賀・近藤、1993）ため、その影響をより湾奥部 で受ける可能性がある。また、湾奥部で冬期の水温低下 によるミドリイガイの生残率が年により異なったり、稚 貝着底の可否が年によって異なったりする可能性も考え られる。しかしながら、本研究では調査区およびハビタッ 卜間における殼長組成が異なる要因を明らかにすること は出来なかった。一方、筏Fのフロート下面の殼長組成

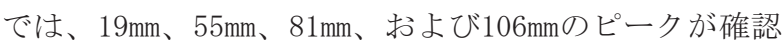
されている。これらがそれぞれ年級群に対応しているか どうかは明らかではないが、款長 $80 \mathrm{~mm}$ を超える個体が多 数採集されていることから、筏のフロート下面における 本種の成長率および生残率は、潮間帯に比べて高いこと が示唆される。ミドリイガイの成長は、プランクトン量 の他、水温や塩分等によって大きく影響を受けるとされ る（劉・渡辺、2002）が、フロート下面は干出にさらさ れることがないことにより、㩒餌や生残に関して潮間帯 よりも好条件であることに要因があるのかもしれない。 植田（2001） は相模湾奥部の江の島の潮間帯に分布する ミドリイガイ個体群について款に形成される阻害輪の数 の変化を追跡し、その輪数の変化が年に 1 回であると仮 定して、越冬後の春期における江の島のミドリイガイ個 体群が、殼長 20-30mmの 0 +年級群、40-50mmの 1+年級 群、60-70mmの 2 +年級群、および80-90mm の $3+$ 年級 群の少なくとも 4 つの年級群から構成されると推定した。 一般に、阻害輪には冬期の成長停止による冬リングのほ かに、生殖時の成長の停滞による産卵リングも形成され る可能性がある（細見、1989）ため、ミドリイガイの年 級群を特定するには、個体群動態と阻害輪を組み合わせ て年級群の特定を検討する必要もあるだろう。

養殖笺などの浮体構造物の下面は常に海面直下にある ために、自然海岸とも人工海岸とも異なり、特にイガイ 
類や管棲ゴカイ類によって特徴づけられる付着生物相を 有する (Holloway and Connell，2002）ため、浮体構造 物が設置されている海域ではイガイ類の現存量が高まる ことが推察される。本研究では、湾内における笺のフロー ト下面のミドリイガイの生息数が、潮間帯の約 5 倍であ ることが推定された。潮下帯の海底にミドリイガイが付 着することも考えられるが、浦ノ内湾では潮下帯はすぐ に砂質または砂泥質となり付着基質が少ないこと、さら に湾央から湾奥部海底は夏期に貧酸素となること（玉井・ 森本、1990 ; 伊賀 - 近藤、1993）から、その個体数は潮 間帯や養殖笺に比べて無視出来ると考えられる。また、 筏に付着するミドリイガイについては、湾口部の筏Eの 密度のみをもとにして算出しているが、定量採集をして いないものの湾央部の筏にも本種が少なからず付着して いることを確認している（山田、未発表）ため、過大評 価とはなっていないと考えられる。浦ノ内湾のように養 殖筏が多い湾では、ミドリイガイの湾全域の動態を把握 するうえで、浮体構造物に付着する個体群の生態が重要 になるだろう。

\section{2. 浦ノ内湾における他の移入イガイ類の動向}

コウロエンカワヒバリガイは内湾および河口域に移入 したイガイ類であり、その動態や生態系への影響が注目 されている（木村、2001）。本種は、1980年代には浦） 内湾の北東約 $15 \mathrm{~km}$ に位置する浦戸湾ですでに定着が報告 され（岩崎ほか、2004）、現在、浦戸湾全域で高密度に 分布しているが、浦ノ内湾で発見されたのは2007年であ る (町田、私信)。本調査において、コウロエンカワヒ バリガイは、塩分のやや薄い湾奥および湾央で計 30 個体 採集され、殼長組成は、18-20mmをピークとする単峰型 であると考えられた。北九州市の洞海湾での研究では、 コウロエンカワヒバリガイは夏期から秋期に加入がみら れ、 5 月には殼長 $10 \mathrm{~mm}$ 前後の $0+$ 年級群と殼長 $20 \mathrm{~mm}$ 前後 の $1+$ 年級群の 2 つのピークを持つことが知られている (小濱ほか、2001)。浦ノ内湾でも加入や成長が同様であ ると仮定すれば、調査時には $1+$ 年級群のみが見られる ことから、昨年夏から秋に新規加入が無かったか、少な かったと考えられる。現時点での本種の浦ノ内湾におけ る分布域は湾奥および湾央であり、まだ個体数はわずか であるが、今後の個体群の推移を注視すべきである。

ムラサキイガイMytilus galloprovincialisは、浦ノ 内湾において 2005 年頃まではフロートやブイの下面によ く見られていたが、ミドリイガイの付着が観察されるよ うになると相前後して減少した（山田、未発表）。また、 Kurihara et al. (in press) によると、ムラサキイガ イは全国的に減少傾向にあることが報告されている。ム ラサキイガイの減少とミドリイガイの増加になんらかの 因果関係があるのかどうかは明らかではない（Yamada et al.，2009）が、羽生・関口（2000）によれば、これ ら 2 種間の空間をめぐる競争や、生息限界温度および繁 殖生態の違いによる種間関係が指摘されている。本研究 ではムラサキイガイは採集されなかったが、2008年 5 月、 本調査とは別の機会に、殼長 $50 \mathrm{~mm}$ のラサキイガイが筏
Fのフロートに付着していたことが観察されている。浦 ノ内湾において、ムラサキイガイは絶滅したわけではな く、低い密度で個体群を維持していると考えられる。し かし、現時点の浦ノ内湾において、ミドリイガイが最も 生息数の多い移入イガイ類である。

\section{3. 自然海岸におけるミドリイガイの生息}

自然海岸に定着したミドリイガイに関しては、相模湾 奥部の江の島で安定した個体群があり、繁殖周期や阻害 輪を用いた成長速度の推定などの研究が行われている （植田、2001；吉安ほか、2004）。しかし、関東地方では ミドリイガイの分布場所の多くは人工基盤であり，自然 海岸に少ないことが報告されている（植田、2001）。本 調查の結果、浦ノ内湾ではミドリイガイは人工海岸（垂 直護岸や石組み護岸）ばかりではなく、自然海岸（岩礁 や転石）にも付着しており、また、その出現率や一定時 間あたりの採集密度は八ビタットの違いによらず同程度 であった。このことは、ミドリイガイが必ずしも人工海 岸に多いとはいえないことを示している。しかし、日本 により早く移入したムラサキイガイについては、人工護 岸に多く、自然海岸には少ないとされ（細見、1989）、 また、北米太平洋岸でも、在来種キタノムラサキイガイ Mytilus trossulus は自然海岸に多く、移入種ムラサキ イガイとそれらの交雑個体は人工海岸に多いという八ビ タットの違いが報告されている（Elliott et al., 2008)。 一方、南アフリカでは、移入したムラサキイガイが自然 海岸にも分布し、在来種のAulacomya ater また、多くの地点で在来種のPerna pernaよりも優占し ている (Branch and Steffani, 2004; Bownes and McQuaid, 2006)。今後、これらの要因を解明するために、移入イ ガイ類の原産地および移入先における生息環境や基質の 相違に関する継続的な調査が求められる。

本研究の潮間帯における調査によると、浦ノ内湾にお ける在来イガイ類のうち水平分布がミドリイガイと重な る種はクログチ、ヒバリガイモドキ、およびクジャクガ イの 3 種であると考えられた。クログチは内湾および河 口域の潮間帯上部に分布し (Kimura, 1996)、ミドリイ ガイは主に潮下帯に分布する（劉・渡辺、2002）とされ る。例えば、相模湾江の島の潮間帯では、クログチは潮 間帯上部に出現し、ミドリイガイは潮間帯中部から下部 に出現するという垂直分布の違いが示されており（植田・ 萩原、2009)、本調査地である浦ノ内湾においても同様 の違いが認められている (山田、未発表)。このように、 2 種の垂直分布は明らかに異なっているため、ミドリイ ガイとクログチの競合は考えにくい。ヒバリガイモドキ は紀伊半島の田辺湾で研究例が豊富であり、ムラサキイ ンコが比較的波当たりの強い海岸に分布するのに対して、 本種はやや遮蔽された海岸に分布することが知られてい る（Iwasaki，1994；原田・小松、1995；大垣、1996）。 本種の垂直分布については、特に潮間帯中部から下部に 出現すること、ムラサキインコと同所的に分布する地点 では相互作用が認められることが実験的に明らかにされ ている（Iwasaki，1994；1995）。一方、クジャクガイの 
分布状況に関する日本での知見はほとんどないが、本調 查地に近い外洋に面した磯では、潮間帯中部で多数のク ジャクガイが出現することが示されている（山田・伊谷、 2008）。植田・萩原（2009）によると、相模湾江の島の 潮間帯では、高塩分で波浪の強い自然海岸の潮間帯下部 に本種の出現が確認されている。本研究の結果とあわせ ると、クジャクガイは湾央から湾外の潮間帯中部から下 部に生息していると考えられる。これらのことから、浦 ノ内湾の潮間帯に生息するクジャクガイとヒバリガイモ ドキは水平分布および垂直分布がミドリイガイと重なっ ており、競合の可能性が示唆された。このようなミドリ イガイによる在来イガイ類との競合は、他地域でも起こ りうると考えられるため、今後、除去実験などを用いた 調査により明らかにする必要がある。また、本研究では、 ミドリイガイと他の付着生物との相互作用についての検 討は行なわれなかったが、潮間帯および潮下帯ともに、 調査中には他の二枚貝類やホヤ類等が数種観察された。 また、ミドリイガイの殼表面を付着基盤として利用する 付着動物の報告もされている（植田・崎山、2001）こと から、浦ノ内湾におけるミドリイガイについても、他の 生物の付着基質や生息場所として利用されている可能性 もある。移入種の在来種への影響の有無を考察するため には、木村（2001）も指摘しているように、移入種およ び在来種について、それぞれの生活史や環境耐性、加入 過程など基本的な生態的知見を得るための今後の研究が 必要である。

\section{謝 辞}

浦ノ内湾の水質データを御提供頂いた高知県水産試験 場、ミドリイガイとコウロエンカワヒバリガイに関する 情報を御提供頂いた高知大学理学部の町田吉彦教授、文 献を御提供頂いた新江ノ島水族館の植田育男氏と社団法 人海洋調查協会、ならびに本論文を校閲して頂き親切か つ適切な御助言を頂いた 2 名の查読者に深く御礼を申し あげる。また、調查に御協力いただいた高知大学総合研 究センター海洋生物教育研究施設の木下泉教授、井本善 次技官、高知大学教育学部海洋共生生物学研究室の岩田 洋輔氏、楪葉顕信氏、西坂太樹氏、三好由佳莉氏に厚く 御礼を申しあげる。

\section{引用文献}

Baker, P., J. S. Fajans, W. S. Arnold, D. A. Ingrao, D. C. Marelli and S. M. Baker (2007). Range and dispersal of a tropical marine invader, the Asian green mussel, Perna viridis, in subtropical waters of the southeastern United States. Journal of Shellfish Research, 26, 345-355.

Bownes, S. J. and C. D. McQuaid (2006). Will the invasive mussel Mytilus galloprovincialis Lamarck replace the indigenous Perna perna L. on the south coast of South Africa? Journal of Experimental Marine Biology and Ecology, 338, 140-151.

Branch, G. M. and C. N. Steffani (2004). Can we predict the effects of alien species? A case-history of the invasion of South Africa by Mytilus galloprovincialis (Lamarck). Journal of Experimental Marine Biology and Ecology, 300, 189-215.
Elliott, J., K. Holmes, R. Chambers, K. Leon and P. Wimberger (2008). Differences in morphology and habitat use among the native mussel Mytilus trossulus, the non-native $M$. galloprovincialis, and their hybrids in Puget Sound, Washington. Marine Biology, 156, 39-53.

Gayanilo Jr., F. C., P. Sparre and D. Pauly (2005). FAO-ICLARM Stock Assessment Tools II, User's Guide. FAO, Rome, Italy, 168 pp.

羽生和弘・関口秀夫 (2000). 伊勢湾と三河湾に出現したミド リイガイ. Sessile Organisms, 17, 1-11

原田英司・小松 結 (1995). 田辺湾域における潮間帯岩礁性 動物の分布. 瀬戸臨海実験所年報, 8, 24-34.

Hasselblad, V. (1966). Estimation of parameters for a mixture of normal distributions. Technometrics, 8, 431-444.

林 芳弘 (2008). 赤潮 - 貝毒調查事業.「平成18年度高知県水 産試験場事業報告書」、高知県水産試験場、pp. 71-92.

Holloway, M. G. and S. D. Connell, (2002). Why do floating structures create novel habitats for subtidal epibiota? Marine Ecology Progress Series, 235, 43-52.

細見涁文（1989）。「ムラサキイガイの生態学」、山海堂、東京、 $137 \mathrm{pp}$.

伊賀秀美・近藤康生（1993）。二枚貝を主な指標とした高知県 浦ノ内湾の戦後約50年間 (1943-1992) の環境変化. 宇佐臨 海実験所研究報告, 13, 11-19.

Iwasaki, K. (1994). Distribution and bed structure of the two intertidal mussels, Septifer virgatus (Wiegmann) and Hormomya mutabilis (Gould). Publications of the Seto Marine Biological Laboratory, 36, 223-247.

Iwasaki, K. (1995). Factors delimiting the boundary between vertically contiguous mussel beds of Septifer virgatus (Wiegmann) and Hormomya mutabilis (Gould). Ecological Research, 10, 307-320.

岩崎敬二・木村妙子・木下今日子・山口寿之・西川輝昭・西 栄二郎・山西良平・林 育夫 ·大越健嗣・ 小菅丈治・鈴木 孝男・逸見泰久 - 風呂田利夫 ・向井 宏 (2004). 日本に おける海産生物の人為的移入と分散：日本ベントス学会自 然環境保全委員会によるアンケート調査の結果から.日本 ベントス学会誌，59, 22-44.

Kimura, T. (1996). Shell morphology and anatomy of Xenostrobus atratus (Lischke, 1871) (Bivalvia: Mytilidae). The Yuriyagai, 4, 97-101.

木村妙子（2001）。コウロエンカワヒバリガイはどこから来た のか? 一その正体と移入経路一。「黒装束の侵入者、外来 付着性二枚貝の最新学」（日本付着生物学会編）、恒星社厚 生閣、東京、pp. 47-69.

Kurihara, T., T. Kosuge, H. Takami, M. Iseda and K. Matsubara (in press). Evidence of a sharper decrease in a non-indigenous mussel Mytilus galloprovincialis than in indigenous bivalves from 1978 to 2006 on Japanese rocky shores. Biological Invasions.

小濱 剛・門谷 茂・梶原葉子・山田真知子 (2001). ムラサ キイガイおよびコウロエンカワヒバリガイの個体群動態と 過栄養海域における環境との関係. 日本水産学会誌, 67, 664-671.

劉 海金・渡辺幸彦 (2002). ミドリイガイの生物学的知見. 海洋生物環境研究所研究報告, 4, 67-75.

宮脇 大・関口秀夫 (2000). 河口干潟におけるベントスの個 体群動態一幼生加入過程の視点から一. 月刊海洋, 32, 647653.

岡 育久子・堀越増興・角本 明 (1991)。東京湾におけるミ 
ドリイガイ (Perna viridis) とその生態. 海洋調査協会調査 委員会第8回技術発表予稿集, pp. 35-38.

大垣俊一 (1996)。 ヒバリガイモドキとムラサキインコの殼長 組成, 生殖腺重量の季節変化と分布変動. Venus, 55, 317327.

大垣俊一 (2007). 田辺湾周辺における移入海産生物の出現傾 向. 南紀生物, 49, 16-22.

Rajagopal, S., V. P. Venugopalan, K. V. K. Nair, G. Van der Velde and H. A. Jenner (1998). Settlement and growth of the green mussel Perna viridis (L.) in coastal waters: influence of water velocity. Aquatic Ecology, 32, 313-322.

Rajagopal, S., V. P. Venugopalan, G. Van der Velde and H. A. Jenner (2006). Greening of the coasts: a review of the Perna viridis success story. Aquatic Ecology, 40, 273-297.

Siddall, S. E. (1980). A clarification of the genus Perna (Mytilidae). Bulletin of Marine Science, 30, 858-870.

玉井恭一・森本晴之 (1990)。底質とベントスからみた浦ノ内 湾の有機污染. 日本ベントス学会誌，38，27-34.

植田育男 (2000). 相模湾におけるミドリイガイの分布. 動物 園水族館雑誌，41（2），54-60.

植田育男（2001）。ミドリイガイの日本定着。「黒装束の侵入者、 外来付着性二枚貝の最新学」(日本付着生物学会編)、恒星 社厚生閣、東京、pp. 27-45.
植田育男・萩原清司 (2009) . 相模湾江の島における潮間帯イ ガイ科二枚貝類相. 神奈川自然誌資料, 30, 41-48.

植田育男・崎山直男（2001）。相模湾江の島に生息するミドリ イガイ殼表面の付着動物。神奈川自然誌資料，22，61-64.

梅森龍史・堀越増興（1991）。東京湾西岸におけるミドリイガ イの冬期死亡と生残の区域差. La Mer, 29，103-107.

山田ちはる・伊谷 行 (2008)。「横浪林海実験所」の教育施設 としての活用に向けて一潮間帯貝類と打ち上げ貝類一。高 知大学教育学部研究報告, $68,165-170$.

Yamada, C., N. Iwasaki, T. Shiraishi and I. Imai (2009). Effect of harmful dinoflagellate Heterocapsa circularisquama on the survival of juvenile mussels, Mytilus galloprovincialis and Perna viridis. Proceedings of the $5^{\text {th }}$ World Fisheries Congress, The $5^{\text {th }}$ WFC Organizing Committee, 6c-1004-356, 1-2.

Yamamura, K. (1999). Transformation using $(x+0.5)$ to stabilize the variance of populations. Researches on Population Ecology, 41, 229-234.

八塚 剛・今村忠茂 $(1965)$. 土佐・浦之内湾の海況について。 宇佐臨海実験所研究報告, 12, 1-22.

横川浩治・鍋島靖信（1998）。瀬戸内海で分布を拡大寸るミド リイガイ。ちりぼたん，29, 7-11.

吉安洋史・植田育男・朝比奈潔 (2004)。相模湾, 江八島にお けるミドリイガイの生殖年周期. Sessile Organisms, 21，1926. 